\title{
Livelihood Diversification Strategies and Their Contributions to Household Income and Food Security in Rural Areas of Ethiopia
}

\author{
Aschalew Aweke Ayele \\ Debre Markos university, Department of Rural Development and Agricultural Extension
}

\begin{abstract}
Agriculture is the major occupation for the majority of rural population in Ethiopia. Although its production and productivity is constrained by backward production technologies, small and fragmented land holdings, irregular/erratic/ rainfall, soil infertility, drought /moisture stress/ and risks associated with climatic variability. In order to cope and recover from the prevailing shocks and stress and support their livelihood, rural households in Ethiopia have engaged in different types of non-farm and/or off-farm income generating activities through combining all or some of their livelihood capitals including physical, human, natural, economic and social endowments. The objectives of this review were to identify type and intensity of livelihood diversification strategies and to assess the contribution of livelihood diversification strategies to household income and food security in rural areas of Ethiopia. This paper mainly depends on reviewing secondary date sources browsed from internet and assessed the type and intensity of livelihood diversification strategies and their contribution to income and food security status of rural households in Ethiopia. This paper also pointed out the existed institutional, social, financial and economic constrains challenges that practitioners have faced for farther policy interventions by governmental and non-governmental organizations.
\end{abstract}

Keywords: Diversification, Household, Income, Food security, Livelihood

DOI: $10.7176 / \mathrm{JESD} / 12-11-02$

Publication date:June $30^{\text {th }} 2021$

\section{INTRODUCTION}

Diversification is a norm in every economy, where farming alone rarely provides sufficient income. In Ethiopia, household access to agricultural land has become a growing problem due to population growth. Average holding is diminishing as plots are subdivided to accommodate newly married sons while the number of landless households is also rising. Often, production takes place on small and fragmented farm plots. Besides these, farm production and productivity is highly affected by backward production technologies, low level of inputs use, irregular/erratic/ rainfall, soil erosion and depletion of nutrients, drought /moisture stress/, crop pests and diseases (Bezabih et al., 2014).

Hence, in the contexts of such unstable, drought prone, limited farm-land, and high population growth environment, income from the agricultural sector alone might not be adequate to provide the means of poverty alleviation and improving household livelihood (FAO, 2018, Gebru et al., 2018). This is because households who engaged only in agriculture in such risky areas are often observed vulnerable to food insecurity being unable to produce enough food to feed their families throughout the year (Yaro, 2006). Hence, diversification of household livelihood strategies is a must to minimize smallholder farmers' vulnerability to risks, food insecurity and poverty (Fikriu et al., 2008).

Yaro (2006) also noted that households in agriculture risky areas of the developing world attempted to reduce the risks often posed by these adverse agro climatic calamities tend to earn an increasing share of their income from non-farm and/or off-farm sources away from agriculture (Yaro , 2006). Similarly, Reta and Ali (2012) indicated that in rural Ethiopia, if there had not been other sources of income apart from agricultural production, rural households may face difficulty to earn enough income to fulfill their basic needs. This suggests the necessity of non- farm and/or off-farm activities to cope and recover from shocks and stresses and then sustain their livelihood (Reta and Ali, 2012; Gebru et al., 2018). Yizengaw et al. (2015) also argued that any development intervention to improve the livelihood and food security status of the rural poor in Ethiopia need to take agriculture along with the non-farm and/or off-farm activities, without undue preference being given to farming as a unique solution to rural poverty (Yizengaw et al., 2015).

The different types livelihood diversification strategies in Ethiopia are generally classified as on-farm only, on-farm plus off-farm, on-farm plus non-farm, and on-farm plus off-farm plus non-farm activities (Amsalu et al., 2014; Yizengaw et al., 2015). These livelihood strategies are mostly pursued by food-insecure households due to land shortage and moisture stress to produce sufficient food for consumption (Yishak et al., 2014; Gebru et al., 2018; Kassegn and Endris, 2021),

Although livelihood diversification is a viable way of to ensure food security and reducing poverty and destitution, little policy efforts have been made to promote them in many SSA countries including Ethiopia (Tesfaw, 2015). The government of Ethiopia in its Sustainable Development and Poverty Reduction Program (SDPRP) singles out poverty reduction as its core objective through raising agricultural productivity continuously 
overtime (MoFED, 2002; Gebru et al., 2018). However this expectation of the government to achieving the goal of reducing poverty only through increasing agricultural productivity and redressing the issues of access to key agricultural resources without giving due emphasis for non- farm and/or off-farm activities not brought about significant improvement in the rural community as observed in many Sub Saharan African countries (Menfes, 2010; Emanuel, 2011). Besides these, there are traditional beliefs that view rural non-farm enterprises as low productive activities. Participants are also challenged by several constraints such as lack of capital due to poor access to finance or formal loan services, poor infrastructure, absence of working places and lack of access to market for their produces (Tesfaw, 2015; Gebru et al., 2018). There is also dynamics in livelihood diversification strategies particularly by the youth who tend to shift from on farm business to different types of non-farm activities (Weldegebriel, 2013). Thus, it is crucial to study the productivity and returns offered by such activities, especially those in which the poor are engaged in, and identify the factors that may affect the ability of the poor to raise productivity and returns in their activities.

\subsection{Objectives of the Review}

\subsubsection{General objective}

The general objective of this review is to assess the contribution of livelihood diversification strategies to household income and food security in rural areas of Ethiopia.

\subsubsection{Specific objectives}

- To identify the type of livelihood diversification strategies in rural Ethiopia

- To assess the contribution of livelihood diversification strategies to household income

- To analyze the contribution of livelihood diversification strategies to household food security.

\section{REVIEW METHODOLOGIES}

This review mainly depends on reviewing secondary data sources browsed from internet. The steps involved to identify relevant resources for the review include searching, screening, eligibility and inclusion. Searching was conducted using the following key terms including, livelihood diversification, on-farm activities, non-farm activities, off-farm activities, income, and food security. Screening was done to eliminate non-relevant records by reading the titles, abstracts and finally the full texts, based on the set inclusion/exclusion criteria. The inclusion and exclusion criteria involved three stages. The first step is to down load articles related with households' choice of livelihood strategies and then retaining those published after 2010 G.C and eliminating those published before this specific year (in fact, old definitions and theories in the retained articles were also taken as they were in the original documents). The second stage is reading the abstract of the retained papers and the last stage is reading the full text of the retained articles. Accordingly, a total of one hundred forty nine articles were downloaded of which fifty three were reviewed.

\section{LITERATURE REVIEW}

\subsection{Definition and Concepts}

\subsubsection{Definition and concept of Livelihood diversification strategy}

Former definitions of livelihood considered only the adequateness of stocks and flows of food and cash to meet basic needs and the capabilities, assets and activities required for a means of living. These definitions however do not clarify show how these adequate stocks and flows of cash come about and also not include the ability on how to avoid, or more usually how to withstand and recover from stress and shocks. Hence, Ellis, (2000) attempt to bring various definitions together and defined livelihood as: "A livelihood comprises the assets (natural, physical, human, financial and social capital), the activities, and the access to these (mediated by institutions and social relations) that together determine the living gained by the individual or household" (Ellis, 2000). Loison, (2015) also defined livelihood as "the maintenance and continuous alteration of a highly varied range of activities and occupations to minimize household income variability, reduce the adverse impacts of seasonality, and provide employment or additional income to the practitioners".

According to Barrett et al. (2002) livelihood comprises people, their capabilities and their means of living including food, income and assets. Here 'assets' refers to Natural capital, Economic capital, Financial capital, Human capital and Social capital. Household size, age, education and health status, experience in farming activities are important human capital assets for households livelihoods. Among these, skilled work force is considered a vital human resource to bring about development. Local informal institutions such as religious institutions, selfhelp groups, small credit schemes and cooperatives can be considered as important social capital assets. These institutions offer mechanisms for the people to help each other in times of need, solve internal conflicts, and thus reducing powerlessness and mitigate adverse effects of immediate social problems. The physical capital may include irrigation, residences/shelter/, transport, access to information, water harvesting and soil conservation structures. Land can be considered as the most valuable natural capital of a household. It may also include water sources, grazing land and fuel wood. Financial capital refers to all resources such as cash, liquid assets (livestock, 
jewelry), pension, and remittances and the like (Kollmair and Juli, 2002). Assets and resources can be either tangible or intangible in nature. Tangible assets are resources and stores where as intangible assets are claims and access (Barrett, et al., 2001). These authors also gave further elaborations on the concepts of resources, stores, assets, claims and access. Accordingly, resources include land, water tree livestock, farm equipment, tools and domestic utilities. Stores include food stocks, stores of value such as gold, jewelry and woven textile, and cash savings in banks of thrift and credit scheme. Assets are often both stores and resources as with livestock, residences, trees and savings. Claims and access are intangible assets of households. Claims are demands and appeals which can be made for material, moral, or other practical support or access. The support may take many forms such as food, implements, loan gifts, or work (Barrett et al., 2002). Claim is made at time of stress and shock or when other contingencies are arise. Claim may be made on individuals or agencies, on relatives, neighbors, patrons, chiefs, social groups or communities or on NGOs, government or international community, including programs for drought relief or poverty alleviation (Ellis, 2000). They are based on combination of right, precedent, social convention, moral obligation and power. Access is the opportunity in practice to use resource, store or service or to obtain information, material, technology, employment, food or income. Services here include transport, education, health, shops and markets. Information include extension service, radio television news paper etc. Out of these tangible and intangible assets people construct and contrive a living using physical labour, knowledge, skill and creativity (Ellis, 2000; Barrett et al., 2002). Livelihoods are diverse at every level, for example, members of a household may live and work in different places engaging in various activities, either temporarily or permanently. Individuals themselves may rely on a range of different income-generating activities at the same time" (DFID 2001).

The concept of livelihood refers to what people do to make a living with the assets that they possessed and what they accomplish by doing it in a particular context. It is also about individuals, households or communities making a living, attempting to meet their various consumption and economic necessities, coping with uncertainties and responding to new opportunities (Scoones, 2000). A livelihood is not conceptualized only as the activities that people undertake to earn their living but also includes their resource endowments, assets that they owned and other factors with which people interact for living (Scoones, 2000).

Livelihood strategies are defined as the range and combination of activities and choices that people make to achieve their livelihood goals, including productive activities, investment strategies, and reproductive choices (Barrett et al., 2001). Similarly, livelihood strategies are made out of activities that produce the methods for household endurance and are the arranged activities that people embrace to assemble their livelihoods (Ellis, 2000). A livelihood strategy is considered sustainable when it can cope with and recover from stresses and shocks maintain or enhance its capabilities and assets, while not undermining its natural resource base (Scoones, 2000). Hence, sustainability of livelihoods according to this author raises many questions that often fall in to two categories: weather a livelihood is sustainable environmentally; in its effect on local and global resources and other assets; and weather it is sustainable socially, that is able to cope with stress and shock, and retain its ability to continue and improve. Livelihood strategies include how people combine their income generating activities, the way in which they use their assets, which assets they chose to invest in, and how they manage to preserve existing assets and income. A livelihood strategy would include activities that generate income to a household. It captures not only what people do in order to make a living, but also resources that provide them with the capability to build a satisfactory living, risk factors they consider in managing their resources as well as the institutional and policy context that either helps or hinders them in pursuit of an improved standard of living. The term livelihood strategies denotes: "the range and combination of activities and choices that people make in order to achieve their livelihood goals" (DFID, 2004).

On the other hand livelihood diversification is defined by several scholars in different ways. It is the scope and combination of activities and choices (Liu \& Liu, 2016); a means of gaining a living (Loison \& Loison, 2016); Livelihood diversification is a major means by which many individuals reduce risk. Farm household diversification refers to income strategies of rural individuals in which they increase their number of activities, regardless of the sector or location (Brandth \& Haugen, 2011; Loison \& Loison, 2016). In the definitions, activities refers to farming, herding, hunting, gathering, wage labour, hawking and trade, artisanal work such as weaving and carving, processing, proving transport services etc. They obviously provide food, cash and other goods to satisfy a wide variety of human needs. The word capability refer to being able to perform certain basic functions, to what extent a person is capable of doing and able (Ellis, 2000). It includes for example to be adequately nourished, to be comfortably clothed, to avoid escapable morbidity and preventable mortality, to lead a life without shame, to be able to visit and entertain one's friends, to keep track of what is going on and what others are talking about.

Livelihood diversification is characterized as a procedure by which household members build various arrangements of exercises and social help capacities in their struggle for survival and to improve their ways of life (Ellis, 1998). According to Khatun and Roy (2012) the livelihood and survival of individuals, households, groups and communities are vulnerable to stress and shock. Vulnerability here has two aspects: external, the stress and shocks to which they are subject; and internal, the capacity to cope. Stress are pressures which are typically 
continuous and cumulative; predictable and distressing, such as seasonal rain fall shortage, rising population or declining resources, declining labour work availability, declining real wage, declining in yield on soils degraded due to salinity, acidity or erosion, declining common property resources and having to go further for searching for fuel, fodder, animal feed and water, declining water table, population pressure leading to reduction in farm size and declining rainfall (Khatun and Roy, 2012). Shocks on the other hand are impacts which are typically sudden unpredictable and traumatic such as fire, floods, epidemics, war, persecution and civil violence, drought, storms, famine, land slips, crop pests and animal and human illness (Khatun and Roy, 2012). Capability thus refers to being able to cope up with stress and shock, and being able to find and make use of livelihood opportunities (Ellis, 2000). Such capabilities to cope up from stress and recover from shock as a means of living include gaining access to and using services and information, exercising foresight, experimenting and innovating, competing and collaborating with others, and exploiting new conditions and resources. Diversification refers to all the attempts undertaken by an individual or a household to find new ways of survival to raise income, reduce environmental risk and endure shocks such as disasters and disease outbreaks (Khatun and Roy, 2012). It is a strategy to cope with economic, environment shock, and an instrument to ease poverty. Livelihood diversification would include both non-farm and off-farm activities undertaken to generate income additional to main household on-farm activities (Ellis 2000; Barrett et al., 2002).

\subsubsection{Food security definition and concepts}

Food security is defined, according to the World Food Summit of 1996, as "Food security exists when all people, at all times, have physical, social and economic access to sufficient, safe and nutritious food which meets their dietary needs and food preferences for an active and healthy life" (World Food Summit, 1996). This commonly refers to people having "physical and economic access" to food that meets both their nutritional needs and food Preferences (WHO, 2010). Food security is a difficult concept to measure since it deals in very broad terms with the production, distribution and consumption of food. It should be stressed that food security and, famine and hunger are not to be confused: food security refers to the availability of food whereas famine and hunger are the consequence of the non-availability of food, in other words the results of food insecurity. Food insecurity is a situation that exists when people lack secure access to sufficient amounts of safe and nutritious food for normal growth and development and for an active and healthy life" (FAO, 2009).

The main causes of food insecurity in Ethiopia are prolonged drought, conflict and insecurity, crop disease, etc. According to FAO (2018), in Ethiopia, prolonged drought conditions are severely affecting the livelihoods in most southern and southeastern pastoral and agro-pastoral areas of SNNPR, southern Oromia and southeastern Somali Regions, where cumulative seasonal rainfall was up to 60 percent below average. In these areas, pasture and water availability have declined to extremely low levels, severely affecting crop production and livestock conditions, leading to large scale animal deaths. Drought or flood causes crop failure and can lead to famine in rain-fed agricultural areas. Both scarcity and excessive water have adverse effect upon crops and livestock, the assets which form the main source of livelihood for subsistence peasants. Drought manifests itself not only in reducing production, but also through the adverse effect it brings about in terms of reducing rural employment and drastic increases of food prices on market, and scarcity of common property resources such water for livestock and irrigation purposes. Drought is the most significant trigger that often leads to transitory food insecurity; a slight change in rainfall often leading to dramatic declines in crop yields. For example, Oxfam estimated that drought alone costs Ethiopia US\$ 1.1 billion per year (Shitarek, 2012). More than one million people are displaced in Ethiopia, most of whom have been displaced by conflict starting in September 2017 and many of whom are displaced along the Oromia-Somali regional border (FEWS, NET and WFP, 2018). In the near-time, this displacement has disrupted households' ability to engage in their typical livelihoods activities, such as seasonal cultivation and raising of livestock, and has resulted in food security crisis in the region where conflict has been reported to be most severe ( Feyisa , 2018).

\subsubsection{Pillars of food security}

Any analysis of food security will examine whether a change from security to insecurity or insecurity to security actually takes place and the probability of such a change happening. Factors that may lead to a situation of food insecurity include non-availability of food, lack of access, improper utilization and instability over a certain time of period as identified by FAO (2009).

Food availability: - food availability refers to the amount of food that is present in a country or area through all forms of domestic production, imports, food stocks and food aid (WFP, 2009, p.170; FAO, 2009). Thus, food availability is a function of production, importation, and food aid, supply factors in food production. Riely et al. (2002) confirms that the term tends to be applied to food available at a regional or national level rather than at household level, which can lead to some confusion as the word "availability" sometimes is used at the micro-level (Riely et al., 2002).

Food access: - refers to the ability of a household to acquire adequate amount of food regularly through a combination of purchases, barter, borrowings, food assistance or gifts". (WFP, 2000, p170; FAO, 2009). Food access consists of three elements, which are physical, economic/financial and socio-cultural. The physical 
dimension can be illustrated by a situation where food is produced in one part of a country but cannot be delivered to another part suffering from lack of food due to inefficient or non-existent of infrastructure to transport that food (OXFAM, 2007). From the economic viewpoint, food security exists when people can afford to buy sufficient food. The idea is that food insecurity arises when food is available but people are unable to afford it (Riely et al., 2002). Access is therefore a demand side issue in food security or economic level of the household to afford the food needed (Benedict, 2011).

Food utilization:- refers to safe and nutritious food which meets household's dietary needs. Since, the availability of and access to food on their own are not enough, thus people should have "safe and nutritious food" that provide them with sufficient energy needed to carry out routine physical activities. Utilization also covers factors such as safe drinking water and adequate sanitary facilities to avoid the spread of disease as well as awareness of food preparation and storage procedures. Utilization therefore covers a range of aspects that hinge on the consumer's understanding of what foods to select and how to prepare and store them (Burchi and De Muro, 2012)

Food stability: - The World Food Summit (1996) says that stability must be present "at all times" in terms of availability, access and utilization for food security to exist (FAO, 2009). Availability at all times of adequate world food supplies of basic foodstuffs to sustain a steady expansion of food consumption and to offset fluctuations in production and prices. Hence, starvation or hunger is the characteristic of some people not having enough food to eat. It is not the characteristic of there being not enough food to eat. Although access is an important factor in food security, it can only prevent hunger if accompanied by stability (Burchi and De Muro, 2012).

\subsection{Theories on Livelihood Diversification Strategies and Food Security}

There are theories that explained why farm households diversify, instead of specializing their livelihood activities. The following are selected for this study.

\subsubsection{Theory on necessity and choice}

The reasons for diversification sought by individuals and households as a livelihood strategy are frequently split into two overarching factors, which are - necessityll or - choicell. This can often be viewed as a contrast between accumulation and survival or corresponds to the migration literature of push versus pull reasons to migrate (UNDP 2009). The extent of risk-taking or aversion behavior of the farm household positively determines the necessity for diversification as a form of insurance (push factors), and conversely may determine negatively the degree of access to other ways of settling and coping with shocks and risks ( pull factor) (Ellis, 2000;). The push factors include loss of production due to drought/moisture/ stress, land scarcity or landlessness, land degradation, nutrient depletion, flood and loss of assets due to other man made factors such ethnic conflicts. Whereas the pull factors include better income from non-farm activities, employment opportunities in urban areas such as wage labour, market access, access to information. Necessity refers to involuntary and desperation reasons for diversifying such as fragmentation of farm holdings on inheritance, degradation of the environment leading to decreasing crop yields, natural or civil disasters like drought, floods or civil war resulting in dislocation and abandonment of previous assets etc (Scoones 2009). Choice, by contrast, refers to voluntary and constructive motives for diversification. For instance, looking for opportunities to earn seasonal salaries, traveling to find work in remote areas, educating children to increase their chances of gaining non-farm jobs, saving money to invest in non-farm companies such as trading, utilizing money obtained off the farm to buy fertilizers or capital equipment for the farm enterprise.

\subsubsection{The food entitlement theory}

A theory by Amartaya sen stated, "Famine is not caused by lack of available food, but rather by a lack of access to food". According to this theory food insecurity affects people who cannot access adequate food (e.g. because of poverty) irrespective of food availability, thus what is available must be accessed by people (Deitchler et al., 2010). A famine can occur even if food supplies are adequate and markets are functioning well and a household with limited farm productivity and low cash may face a challenge to acquire food in time of food shortage though market. That is why, this theory is also referred as "Frailer of Entitlement Exchange or FEE in short". According to the proposed theory, famines are due to an inability of a person to exchange his entitlements rather than to food unavailability.

A person is said to suffer from the failure of food entitlement when his/her entitlement set does not contain enough food to enable him/her to avoid starvation in the absence of non-entitlement transfers, such as charity. It means that no matter how a person may reallocate resources to obtain the food he/she wants, she cannot get the minimum amount needed to escape starvation. A famine occurs when a large number of people within a community suffer from such entitlement failures at the same time. Sen makes a powerful case that starvation is not a simple matter of available food supply per capita, but rather a function of entitlement relationships, such as ownership exchange, employment, and social security rights. According to this author, even in a famine, food may be available but people starve because of inability to command food since they may not have the money to buy it or the socially and politically sanctioned right to receive it free. 
There are several kinds of relationships which can give people command of food; inheritance or purchase of agricultural land to grow adequate food; employment which brings in wages to buy food; sociopolitical rights, whether they be religious or moral obligations of some groups to see that others are fed, or institutionalized government-sponsored welfare or social security rights. Starvation is caused by the collapse of people's endowment entitlements (their earned or otherwise acquired set of entitlements to food) or of an unfavorable shift in the distribution of exchange entitlements.

\subsection{Analytical Frameworks}

Different researchers including Gebru et al. (2018), Ayana et al. (2021); Dereje (2016); and Mohamed (2007) have employed different type of descriptive statistical tools such as percentage, frequency, mean and standard deviation. They also employed inferential statistics such as ANOVA f-test, t-test, and chi-square to analyze income difference between households who engaged in different types of livelihood diversification strategies. Kimty Seng (2015), Chang and Mishra (2008); and Ana Damena and Demmelash Habte employed probit model to analyze determinants of household's decision to participate in nonfarm activities.

Gebru et al. (2018) employed relative community based wealth ranking method to understand the difference in household's choice of livelihood diversification strategies among the better off, less poor and poor households. A two stage least square probit model was adapted to analyze the effect of livelihood diversification index on the income of farm household by David et al. (2001) and Negatu (2004) following Barret (2001). Similarly, Bahiru (2016) and Ana and Demelas (2017) also employed Two-Stage Least Square model and Composite Entropy Index (C.E.I.) to analyze the effect of LHDS on household income on household income in Kachabira wereda, Kembata Tembaro zone of the SNNPRS and found that income earned by household has strong bond with the nature and type of the livelihood diversification strategy.

Measuring food security status is an important issue to help decision making, development planning and type of intervention in food-insecure areas. Most former researchers employed cross- sectional data to measure household food security status. Cross sectional data saves time and is cost effective (Ahmad, 2010; Yizengaw, 2014).However, may not provide adequate and representative information and is affected by seasonal variability as household's food consumption trend. It will also lead to selection bias and endoguinity problems (Kimty, 2015; Adem, 2018). Thus longitudinal or time series data is preferred though is costly.

Different researchers employed different types of econometrics models to measure households' food security status such as HFIAS or HDDS or IDDS. For instance, Seyfe employed HFIAS to measure food security status of households. Others preferred dietary diversity measurement brecause it helps to measure not only the ability of a household to afford for food but also the diversity in the diet that a household consumed. Dietary diversity can be measured in two ways including Individual Dietary Diversity Score (IDDS) and Household's Dietary Diversity Score (HDDS). Individual Dietary Diversity Score (IDDS) measure nutritional quality of an individual's diet whereas Household's Dietary Diversity Score (HDDS) refers to the economic ability of a household's access to variety of foods.

Former researchers also employed household kilocalorie intake to measure food security. Kilocalorie measurement is convenient from analytical point of view. However, it measures only energy intake but not help to indicate dietary diversity and nutritional adequacy. PSM model was employed to analyze the impact of livelihood diversification strategies to household income. The PSM model however cannot control for the unobserved confounders that influence both the treatment and outcome and thus, potentially produces inconsistent and biased estimates of the economic effects of nonfarm activities.

Seyfe (2020) employed Multinomial probit regression model to investigate the linkage among livelihood activities and food security. The rationality for selecting multi-nominal probit model by Seyfe (2020) was that, regarding estimation, both multi-nominal logit and probit estimate the effect of explanatory variables on dependent variable involving multiple choices with unordered response categories (Greene. 2000). It is a simple extension of the binary choice model and is the most frequently used model for nominal outcomes that are often used when a dependent variable has more than two choices. But multi-nominal logit model has strong assumption (independent of irrelevant alternative). The normal solution to relax these assumptions is multi-nominal probit regression (Greene, 2000).

\subsection{Conceptual Framework}

The conceptual framework for this study is chosen based on the understanding of livelihood outcomes i.e. income, food security and dietary diversity strongly related to the household livelihoods. Thus sustainable Livelihood Framework (SLF) is used to identify the explanatory variables. Sustainable livelihood framework helps to understand how people cope with stresses and shocks using their capabilities, assets and strategies and to secure their livelihood outcomes (Ellis and Allison, 2004). It also describes factors affecting household's livelihood. The five components that constitute SLF are vulnerability context, livelihood assets, livelihood strategies, structures and processes and livelihood outcomes. The vulnerability context describes the external environment that people 
live in like critical trends (population trends or technological trends), shocks (natural disasters or economic inflation), and seasonality (the way prices, employment opportunities production and dietary diversity might shift with the seasons) (Ellis, 2000).

The term "Assets" in the framework refers to Natural capital, Economic capital, Financial capital,

Human capital and Social capital. Scoones (2000) also noted that people should successfully combine all or some of these-capitall endowments in order to sustain their livelihood. A livelihood framework also takes into account the role played by structures, institutions, policies and processes in influencing the choice of livelihood strategies by the rural poor (Ellis ,2000; Ibekwe et al., 2010). Thus, SLF appreciates policies, institutions and processes that operate at all levels-from the household to the international arena. Livelihood strategies comprise a combination of activities and choices that people undertake in order to achieve their livelihood goals (Ellis and Allison, 2004). The ultimate goal of livelihood diversification is therefore bringing sustainable livelihood outcome (Ellis, 2000). The livelihood outcomes are achievements of livelihood strategies such as more income, increased wellbeing, increased welfare, reduced vulnerability, improved food security and environmental sustainability (Ellis, 2000; Shahbaz, 2008).

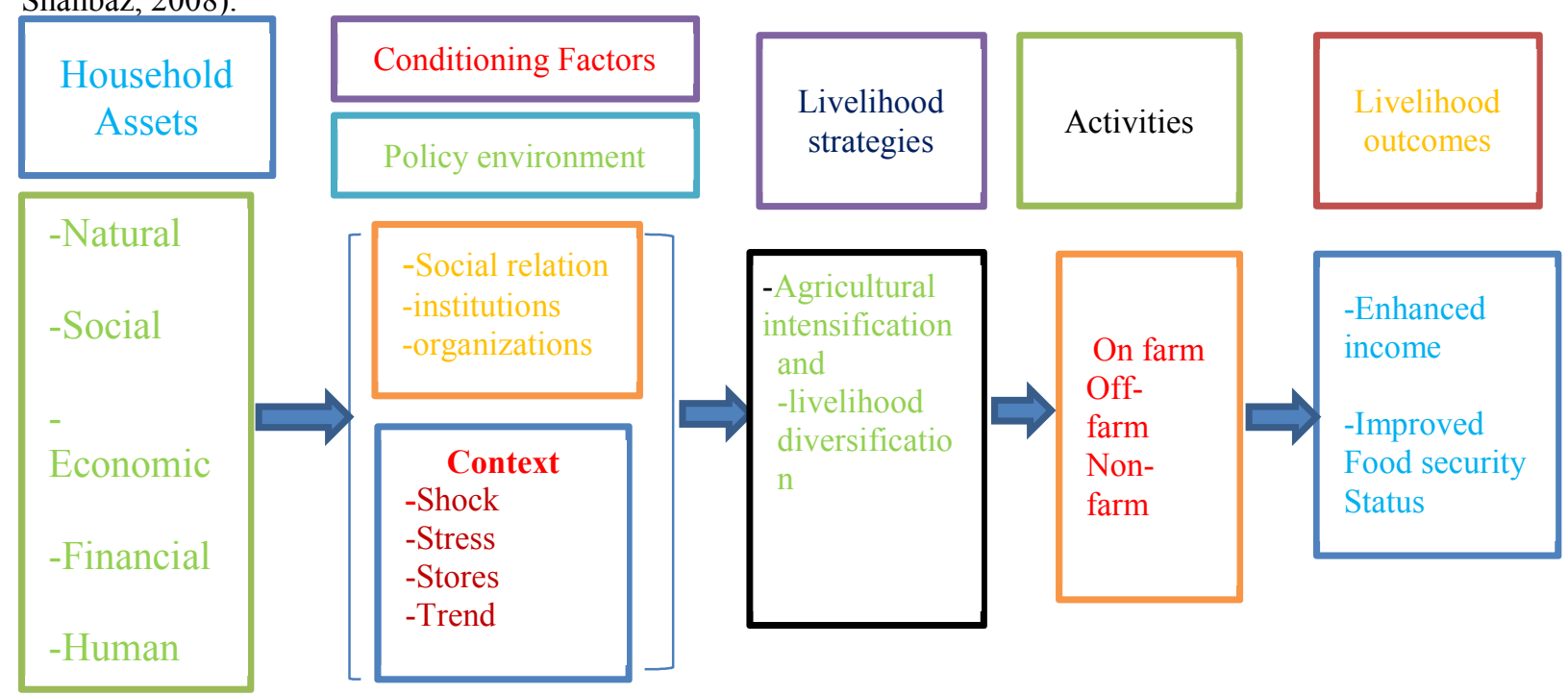

Figure 1.Conceptual framework on sustainable livelihood

Source:- adapted from Ellis, (2000)

\subsection{Empirical Evidences}

\subsubsection{Choice of Livelihood Diversification Strategies in Ethiopia}

Rural households in sub-Saharan Africa in general and in Ethiopia in particular rely on farming and exploitation of natural resources (Belay \& Bewket, 2015; Bezabih, gebru et al., 2018). Although agriculture remains the main source of income and employment, rural non-farm and off-farm income are gaining importance in most rural areas of Ethiopia (Zerihun and Martin, 2013). Different scholars also mentioned several types of livelihood diversification activities in Ethiopia that generally classified as on-farm only, on-farm plus off-farm, on-farm plus non-farm, and on-farm plus off-farm plus non-farm (Ellis, 2000; Barrett et al., 2001; Yizengaw et al., 2015). Household's choice of livelihood diversification strategies in Ethiopia vary based of the extent of risk-taking or aversion behavior of the farm household and matches with in the theory of necessity verses choice driven by push and pull factors. The livelihood diversification in Ethiopia ranges from a temporary change of household livelihood portfolio (occasional diversification) to a deliberate attempt to optimize household capacity to take advantage of ever-changing opportunities and cope with unexpected constraints (strategic diversification) (DFID, 2004). In Ethiopia, in the face of low agricultural productivity, destitute households with fewer non-agrarian skills are pushed into low-paid non-farm activities to maintain food security. In the country, the percentage of households' participation in non-agrarian income generating activities is $27 \%$ at national level (Gebrekidan et al., 2021).

Livelihood diversification Strategies can have both positive and negative impacts on rural household's livelihoods and to the environment too as stated in the theory of nexus between environment and livelihood. Its impact is positive when households are more secure and reduce adverse impact of seasonality such as reduction in the number of months with shortage of food, but it can result in negative effect when it increases households' vulnerability for different risks such as natural resource degradation, and increasing the work burden on women, reducing women's time spent for caring infants, and increased absentees of children from school to help their families engaged in non-farm businesses (Ellis, 2000).

There is variability in households' choice of LDS by sex, age, wealth category and ACZs based on the risk 
taking or risk aversion behavior of farmers. For instance, the importance of non-farm and/or off farm activities in Ethiopia varies by region and livelihood zone (LIU, 2011). The most important source of cash income for most rural households is crop sales in the cropping livelihood zone (broadly comprising Tigray, Amhara, Beneshangul Gumuz, Gambella, South Region and the western and northern parts of Oromiya) and livestock sales in the pastoral and agro-pastoral zones (roughly corresponding to Somali and Afar) (LIU, 2011). Migrant labour is common in the parts of Amhara and Tigray that were the epicenter of famines in the 1970s and 1980s. In these areas, income from migrant labour ranges from $31 \%$ to $54 \%$ of the total household income whereas income from non-farm and off-farm activities such as petty trading and self-employment constitutes up to $60 \%$ of households' income in other parts of the country (LIU, 2011). Petty trading is significant in densely populated areas of the SNNPRS. The collection of firewood and grass for fodder sales (defined as self-employment by LIU, 2011) is common in the lowlands and pastoral areas. Income from firewood and charcoal sales contributes more than 9\% of total cash income in Western Tigray, Southern Amhara, Southern Afar and the southern foothills of Hararge (LIU, 2011; Zerihun and Martin, 2013).

Households' choice of livelihood diversification strategies also varies by agro ecologies and access to infrastructures like road. Unequal distribution of household resource and asset will force households to diversify into a high return sector (to enhance their wellbeing), and low return sector. For Gebru et al. (2018) household's choice of livelihood diversification strategies vary by their respective wealth category. The poor and less poor households engage in low risky and low return livelihood diversification activities with their primary objectives of survival, reducing climatic related risks like drought, and looking for additional money to cover family expenditure like educational fees whereas the objective of the better-off households is for better wealth accumulation and better living (Gebru et al., 2018). Accordingly, the income earned has been strong bond with the nature and type of the livelihood diversification strategy that a household in a given category has chosen.

\subsubsection{Contribution of livelihood diversification strategies on household income}

Livelihood diversification is mostly measured by using income earned from different activities/sources either in cash or in kind (Barrett et al., 2001). A study conducted in Eastern part of Tigray, Saesietsaeda Emba wereda, by Gebru et al. (2018), showed that farm households in the study area are forced to diversify their livelihood income sources beyond agricultural income and found greater variability in households' choices of livelihood diversification strategies and amount of income earned by households in accordance to the type of activity that they are engaged in. In his study the analysis of variance (ANOVA) showed the presence of a significant mean difference between rural households falling in the four livelihood strategies in terms of total annual cash income. He tried to disaggregate income from different sources into categories and sub-categories to reflect the different features of the resources required to generate them, and their seasonality, accessibility and location. Accordingly, those farmers who used combination of on-farm, off-farm and non-farm activities as their livelihood strategy had earned relatively better total annual cash income than the others. The mean value of total annual cash income earned by those farmers relying on combination of on-farm, off-farm and non-farm activities was Birr 23200, while it was Birr 17900, 8554 and 7712.6 for those households relying on on-farm plus non-farm, on-farm plus off-farm and on-farm alone to drive their livelihood respectively.

Similarly, Seid (2016) in his study in western part of Ethiopia employed ANOVA (F-test) and chi-square test to make comparisons (to make sure the presence or absence of difference) between the livelihood groups of the households. Seid, (2016) found significant variation in annual cash income from different livelihood diversification strategies by wealth category. The better off and the poor households earned a mean annual income of ETB 14663.15 and 6783.44 respectively from on-farm activities. Off-farm activities contribute a mean annual income of $\mathrm{Br} 2615.59$ and 1552.30 for the better of and poor respectively. Regarding the non-farm income the better of earned a mean annual income of $\mathrm{Br} 10297.92$ whereas the poor earned only $\mathrm{Br} 2586.74$ implying that income earned has strong bond with the nature and type of the livelihood diversification strategy. This statistical analysis also clearly showed the existence of significant income difference among the poor, less poor and better off households.

\subsubsection{Impact of Livelihood diversification on household food security}

People's livelihood sources determine their ability to acquire food (Fashogbon and Oni, 2012). The main means of acquiring food include production, own labor, trade and transfer entitlements (Oni and Fashogbon, 2012). Households secure their food access based on the activity they undertake. Not all households get their food from own production. If households cannot produce enough food by their own, their income level and food availability in the market determines their food entitlement. Even households who are dominantly agrarian themselves might found to be market dependent since annual production could not support their year round consumption. In this case purchase from market might be an alternative source to acquire food (Oni and Fashogbon, 2012).

Dereje (2016) conducted a study to measure the food security status of the rural poor in Sululta district of Oromiya Regional State using HFIAs and the result revealed that those who engage in different livelihood diversification strategies are more food secure than those who stick only on on-farm activities. Accordingly, $43 \%$ of the sample households were identified as food secure and from whom $2.3 \%$ involve in on-farm only, $23.3 \%$ 
involve both in agricultural and non-farm livelihood activities, and the rest $17 \%$ involved in on-farm plus off-farm activities (Dereje, 2016).

Dereje (2016) also showed the food acquiring entitlement of households with respect to their choice of livelihood diversification strategies. Accordingly, $69.3 \%$ of the households acquired food from own production. These include $39.5 \%$ and $29.8 \%$ of households who engage in on-farm only, and on-farm plus non-farm activities respectively. On the other hand $28.4 \%$ households acquired food by purchasing from the local market. These include $7.5 \%, 14.4 \%$ and $6.5 \%$ households who engaged in on-farm only, on-farm plus off-farm, and on-farm plus non-farm activities respectively. The rest $2.3 \%$ including $0.5 \%$ from on-farm only, $0.5 \%$ from on-farm plus offfarm and $1.3 \%$ from on-farm plus non-farm sectors were found food aid beneficiaries. From this it can be concluded that dominantly agrarian households themselves were found to be market and food aid dependent since annual production could not support their year round consumption (Dereje, 2016). The result of the ANOVA FTest in Seyfe's (2020) also showed that mean of HFIAS score significantly differ with respect to the three livelihood portfolio at one percent. Hence, livelihood strategies of the respondent were confirmed to affect/support household food security $(\mathrm{p}=0.000)$. He also showed that those household who used farming livelihood activities are relatively food secure and the household using non farming activities for their livelihood are more food insecure. Titay (2017) also found significant difference in the food security status of diversified and not diversified households. Her result showed that those who diversify their livelihood activities consumed a mean energy of 2561 $\mathrm{kcal} / \mathrm{AE} /$ day with a standard deviation of 352.25 where as those who not diversified consumed 1939 $\mathrm{kcal} / \mathrm{AE} /$ daywith a standard deviation of $479.7 \mathrm{kcal}$. This coincides with the results of an endogenous switching model (two stage least square) by Kimty Seng (2015) who showed that engaging in nonfarm activities, rural farm households make positive gains in per capita food consumption implying that engagement in nonfarm activities exerts positive effects on household food consumption in Cambodia.

\section{CONCLUSION}

Diversification of household livelihood strategies is a must and has positive implication on smallholder farmer's income and in minimizing risks and shocks. They help the rural poor to build livelihood capitals and become less vulnerable to risks associated with natural catastrophes such as climate change, rain fall variability, drought, land degradation, pest and disease prevalence etc, that ultimately lead to low level of agricultural production and productivity and thus to low level of income. It is difficult for smallholder farmers to live depending only on agricultural income alone and hence need to engage in different types of off-farm and non-farm activities.

There is variability in households' choice of LDS by sex, age, wealth category and ACZs based on the risk taking or aversion behavior of farmers. LHDS can have both positive and negative impacts on rural household's livelihoods and to the environment too as stated in the theory of nexus between environment and livelihood. Some Livelihood diversification strategies like renting equines even contribute not only for the LH of the rural poor but also for the Extension service. Others (for example motor bike renting and contraband trading) led to loss of valuable livelihood assets such as land. Other livelihood diversification strategies like sale of fuel wood and charcoal might have adverse effect on the environment. Even some livelihood diversification strategies for example motor bike renting and contraband trading as observed in some parts of SNNPRS.

People's livelihood sources conditions their ability to acquire food. Households secure their food access based on the activity they undertake. Households who diverse their livelihood activities combine their income from both agriculture and non-farm activities to fill their food gap during time of food shortage than those who engage only in on-farm activities. The average number of months for which own food stock support household consumption was also higher for households who combine both agricultural and non-farm livelihood activities than those who rely only on on-farm activities. This implies the importance of livelihood diversification strategies to enhance households' food security. However, majority of previously conducted researches outputs not consider the importance of livelihood diversification strategies on households' dietary diversity.

In conclusion, undertaking viable livelihood strategies is a determining factor for the realization of households' food security. Those who combine agricultural and non-farm livelihood activities were more likely to support their year round consumption than those who are pursuing agricultural activities only. Not all households get their food from own production. If households cannot produce enough food for their own, their income level and food availability in the market determines their food entitlement. Households who are dominantly agrarian themselves could face food shortage and be market dependent if annual production could not support their year round consumption. Special attention is needed in drought prone areas to encourage households to diversify their livelihood strategies and to reduce migration and loss of livelihood assets including human life as a result of the prevailed drought. Moreover, further studies that focus mainly on the importance of livelihood diversification strategies on households' dietary diversity should be conducted particularly in drought prone rural areas of Ethiopia.

\section{REFERENCES}

1. Amsalu, B., Kindie, G., Belay, K. and Chaurasia, S. P. R. 2014. "The role of rural labor market in reducing 
poverty in Western Ethiopia", Journal of Development and Agricultural Economics, Vol. 6, No.7, pp. 299308. DOI 10.5897/JDAE2013.0518.

2. Andrew Dorward1, Simon Anderson2, Susanne Clark3, Bernadette Keane and Julieta Mogue ,2014. Asset Functions and Livelihood Strategies: A Framework for Pro-Poor Analysis, Policy and Practice ADU Working Paper 01/01

3. Barrett, C. B., Bezuneh, M., \& Aboud, A. 2001. Income diversification, poverty traps and policy shocks in Côte d"e Ivoire and Kenya.

4. Bahiru 2016. Effect of non farm income on household income.

5. Belay, M., \& Bewket, W. 2015 . Enhancing rural livelihoods through sustainable land and water management in northwest Ethiopia. Geography, Environment, Sustainability, 8, 79-10

6. Benedict, A.O.2011. "The People - Food Predicament in Africa: The Quest for Food Security." International Journal of Humanities and Social Science 1(19):257-268.

7. Bezabih M, Gebreegziabher Z, Gebremedhin L, Kohlin G.2010 . Participation in Off-Farm Employment, Rainfall Patterns, and Rate of Time Preferences: The case of Ethiopia. Environment for Development Discussion Paper Series, EfD DP 10-21

8. Bowen, S., \& De Master, K. De 2011. New rural livelihoods or museums of production? Quality food initiatives in practice. Journal of Rural StudiesBrandth \& Haugen, 2011;

9. Burchi and Muro 2012: Burchi, F. \& De Muro, P. 2012. A Human Development and Capability Approach to Food Security: Conceptual Framework and Informational Basis. Working Paper 2012-009: United Nations Development Programme. 11

10. Chambers R, Conway G.1992. Sustainable Rural Livelihoods: Practical Concepts for the 21st Century. IDS Paper No. 296. Sussex: Institute of Development Studies.

11. Davis, J. R. (2003, July). The rural-non-farm economy, livelihoods and their diversification: Issues and options. Livelihoods and their diversification: Issues and options. doi:10.2139/ssrn.691821

12. Delden, L. V., Dominiak, M., Fouch, H. J., Van Der Westhuizen, H. C., Oomen, R. J., Preez, C. C., \& Amelung, W. 2015 . Rangeland management effects on soil properties in the savanna biome, South Africa: A case study along grazing gradients in communal and commercial farms. Journal of Arid Environments, 120, 14-25 Djalilov, Khamzina, Hornidge, \& Lamers, 2016;

13. Dereje Tesema 2016. Rural Livelihood Strategies and Household Food Security: The Case of Farmers Around Derba Cement Factory, Sululta Woreda, Oromia Regional State

14. Devereux,S, Bob Baulch, Karim Hussein, Jeremy Shoham Helen Sida, and David Wilcock.2004. Improving the Analysis of Food Insecurity Food Insecurity Measurement, Livelihoods Approaches and Policy: Applications in FIVIMS. Institute of Development Studies,University of Sussex.Emanuel, 2011

15. DFID. 2004. Agriculture, hunger and food security. Agriculture and Natural Resources Team, UK

16. Ellis F (2000). Rural livelihoods and diversity in developing countries.

17. Ellis F, Allison E.2004.. Livelihood diversification and natural resource access. Overseas Development Group, University of East Anglia, FAO, Livelihood Support Program

18. FAO.2009. Declaration of the World Summit on Food Security. World Food Summit 16-18 November 2009. Rome.

19. Fikru Tesfaye 2008. A Case Study Of Non-Farm Rural Livelihood Diversification In Lume Woreda, Oromiya Reginonal State of Ethiopia. A Thesis Submitted to the School of Graduate Studies Addis Ababa University

20. Gebru Weldegebrial Gebru1*, Hyacinth Ementa Ichoku2 and Philip Ogbonnia Phil Eze3 2018. Choices and implications of livelihood diversification strategies on smallholder farmers' income in Saesietsaeda Emba District, Eastern Tigray Region of Ethiopia

21. Gebru, G. W., \& Beyene, F. 2012 . Rural household livelihood strategies in drought-prone areas: A case of Gulomekeda District, eastern zone of Tigray National Regional State, Ethiopia.

22. Geleta Fekadu Ayana, Tebarek Lika Megento, Fekadu Gurmessa Kussa 2021. The extent of livelihood diversification on the determinants of livelihood diversification in Assosa Wereda, Western Ethiopia

23. Haggblade, S, Hazell, B and Reardan T. 2006. The Rural Non- Farm Economy: Pathway out of Poverty or pathway in? Transforming The Rural Non-farm Economy (Baltimore, John Hopkins

24. Karen Charlton, 2016. Food security, food systems and food sovereignty in the 21 st century: A new paradigm required to meet Sustainable Development Goall MSc., M.Phil (Epi), PhD AdvAPD RPHNutr

25. Khatun D, Roy BC. 2012. Rural livelihood diversification in West Bengal: determinants and constraints. Agric Econ Res Rev 25(1)

26. Gebrekidan*1,Komikouma Apelike ${ }^{2}$ and Wobuibe Neglo ${ }^{2}$, and Kaiyu Lyu ${ }^{2}$ 2021. The Role of Agriculture and Non-Farm Economy in Addressing Food Insecurity in Ethiopia: A Review

27. Kollmair M, Juli G.2002 . The sustainable livelihoods approach. Paper for the integrated training course of NCCR, North-South Aeschiried, Switzerland.

28. Livelihood Integration Unit, LIU 2011. Atlas of Ethiopia Disaster Risk Management and Food Security 
Sector, Addis Ababa Ministry of Agriculture and Rural Development /MoARD/ http.//feg.consulting.com/spotlight/complete atlas .

29. Loison, S. A., \& Loison, S. A. 2016 . Rural livelihood diversification in Sub-Saharan Africa: A literature review rural livelihood diversification in Sub-Saharan Africa: A literature review.

30. Luca, A., D’Errico, M., and Mane, E., 2010. Livelihoods strategies and household resilience to Food insecurity: an empirical analysis to Kenya. Organized by the European report of development in Dakar, Senegal

31. Menfese Tadesse , 2010. Living with Adversity and Vulnerability : Adaptive Strategies and the Role of Trees in Konso, Southern Ethiopia: Doctoral Thesis; Swedish University of Agricultural Sciences , Faculty of Natural Resources and Agricultural Sciences Department of Urban and Rural Development Uppsala Nigeria:University of Ibadan.

32. Ministry of Finance and Economic Development). 2002. Ethiopia: Sustainable development and poverty reduction program (SDPRP). Addis Ababa: MoFED

33. Oni,O, and Ayodele E. Fashogbon. 2012. Food poverty and livelihood issues in rural Nigeria.

34. OXFAM, 2007. Market Analysis Tools in Rapid-Onset Emergencies Phase One Report

35. Popkin 2003. "The nutrition transition in the developing world." Development Policy Review 21 (5-6):581597

36. Reardon, T., and C. P. Timmer. 2007. "Transformation of markets for agricultural output in developing countries since 1950: How has thinking changed?" Handbook of agricultural economics 3:2807-2855

37. Reta H, Ali H 2012 . Livelihood Diversification among the Agricultural Land Scarce Peasants in the Central Highlands of Ethiopia. Int. J. Agric. Sci. Res. Technol. 2(1):1-8. Available online at: www.ijasrt.com. Accessed on 15 March, 2013

38. Robert Chambers and Gordon R. Conway 1991. Sustainable Rural Livelihoods: Practical Concepts for the $21^{\text {st }}$ Century.

39. Scoones Ian 2000 . Sustainable Rural Livelihoods: a framework for analysis, IDS Working Paper no. 72 , Brighton: Institute for Development Studies.

40. Seid 2016. Determinants of Rural Households Livelihood Strategies: Evidence from Western Ethiopia

41. Shahbaz B. 2008 . Risk, vulnerability and sustainable livelihoods: Insights from northwest Pakistan. Sustainable Development Policy Institute, Islamabad, Pakistan

42. Seife T. 2018. Ethiopia Country Report (Addis Ababa, Ethiopia). Available online at:https://www.gov.uk/government/uploads/system/uploads/attachment_data/file/197474/Econ-Res (accessed June, 2013).

43. Tesfaw W.2015 . MA Thesis on Challenges and Opportunities of Livelihood Diversification: The Case of Pastoral Communities in Yabelo Woreda, Borana Zone, Ethiopia. Indira Gandhi National Open University School of Continuing Education. Addis Ababa, Ethiopia.

44. Tizita Mulugeta, 2013: Female Headed Households and Their Livelihood in Bati Wäräda, South Wollo:

45. Weldegebriel, Zerihun; Prowse, Martin Philip 2013. Climate change adaptation in Ethiopia: to what extent does social protection influence livelihood diversification?

46. WFP, 2009: Emergency Food Security Assessment Handbook.

47. Woldehanna, T. 2002. 'Rural Farm/Non-Farm Income Linkages in Northern Ethiopia', in B. Davis (ed.), Promoting Farm/Non-Farm Linkages for Rural Development: Case studies from Africa and Latin America. Rome: Food and Agriculture Organization.

48. World Bank 2011. Project Performance Assessment Report. Ethiopia Productive Safety Net Project. IEG Public Sector Evaluation No. 62549. Washington, DC: World Bank http:// www. oecd. Org /countries/ ethiopia/

49. Yaro and Hesselberg 2006. Livelihood Diversification Strategies in Rural Ghana

50. Yizengaw 2015. Eric Ndemo Okoyo Fekadu Beyene,2015: Determinants of livelihood diversification strategies: The case of smallholder rural farm households in Debre Elias Woreda, East Gojjam Zone, Ethiopia

51. Young,H.,Sussane,Jaspars, Rebecca Brown, Jackie Frize, and Hisham Khogali. 2001. Food Security Assessments in Emergencies: A Livelihood Approach. Humanitarian practice network paper. London: Overseas Development Institute.

52. Zerihun and Martin, 2013. Climate-Change Adaptation in Ethiopia: To What Extent Does Social Protection Influence Livelihood Diversification? 


\section{ABBREVIATIONS/ACRONYMS}

BOA Bureau of Agriculture

DFID Department for International Development

DPPD Disaster Prevention and Preparedness Department

FAO Food and Agricultural Organization

FGD Focus Group Discussion

HFIAS Household Food Insecurity Access Scale

LIU Livelihood Integration Unit

MOFED Ministry of Finance and Economic Development

NGOs Non-Governmental Organizations

SDPRP Sustainable Development and Poverty Reduction Program

SNNPRS Southern Nation Nationalities and People's Regional State

WB World Bank

WFP World Food Program 